\title{
Intensitas Serangan Semut pada Tanaman Buah Naga (Hylocereus sp.) di Kota Pariaman, Sumatera Barat
}

\section{The Intensity Attack of Ant on Dragon Fruit (Hylocereus sp.) in Pariaman City, West Sumatera}

\author{
Halimah Tus Sakdiah"), Henny Herwina dan Mairawita \\ Laboratorium Taksonomi Hewan, Jurusan Biologi, FMIPA, Universitas Andalas, Padang, \\ Sumatera Barat 25163 \\ *) koresponden: halimah1110423038@gmail.com
}

\begin{abstract}
A study about the intensity attact of ant in dragon fruit (Hylocereus sp.) plantation was conducted on September 2015 in Pariaman City, West Sumatera. The ants were collected by using free collection method with purposive sampling techniques. About $10 \%$ of the dragon fruit plant in the study location was observed. The result showed that the intensity attack on dragon fruit was caused by fire ant Solenopsis geminata $(25 \%)$.
\end{abstract}

Keywords: ant, Intensity attack, dragon fruit

\section{Pendahuluan}

Buah naga (Hylocereus) merupakan kaktus liar yang berasal dari wilayah di Amerika Tengah dan Amerika Latin (Meksiko dan Kolombia). Saat ini spesies ini telah menyebar ke seluruh dunia terutama daerah tropis dan subtropis (Zee, Yen, dan Nishina, 2004). Tanaman buah naga mulai masuk ke Sumatera Barat sejak lima tahun terakhir. Tempat yang menjadi sentra penanaman adalah Kabupaten Padang Pariaman, Pasaman, Kabupaten Solok dan Padang (Jumjunidang, Riska dan Muas, 2012).

Menurut McMahon (2003) buah naga tidak luput dari serangan hama dan penyakit. Terdapat dua penyakit yang paling sering dijumpai yaitu busuk lunak batang dan antraknosa. Penyakit pada buah naga disebabkan oleh infeksi dimulai dari area luka (khususnya jaringan batang) yang disebabkan oleh gigitan serangga, namun sampai saat ini belum teridentifikasi jenis serangganya.
Mairawita (2002) melaporkan adanya indikasi yang kuat bahwa serangga berperan penting dalam penyebaran penyakit pada beberapa tanaman perkebunan. Herwina dan Yaherwandi (2102) melaporkan jenis-jenis semut pada perkebunan kakao dan (Herwina et al., 2013) mengenai jenis-jenis semut pada tanaman pisang yang terjangkit gejala Banana Bunchy-top Virus (BBTV).

Semut tergolong hama pada tanaman buah naga karena menyebabkan kerusakan pada masa pembungaan dan pembuahan (Bellec, Vailant dan Imbert, 2006). Data Department Agriculture of US (2011) menemukan empat spesies semut hama untuk buah naga di Thailand. Merten (2003) melaporkan bahwa semut yang menjadi hama di perkebunan buah naga berasal dari genus Solenopsis yang tergolong semut invasif. Di Sumatera Barat Herwina et al., (2014) menemukan lima jenis semut hama pada perkebunan buah naga yaitu: Monomorium floricola, Solenopsis geminata, Pheidole sp., 
Tapinoma melanocephalum, dan Paratrechina longicornis. Menurut Invasive Database (2016), kelima jenis semut ini tergolong semut invasif.

Perkebunan buah naga Sumatera Barat terdapat diantaranya di Nagari Kurai Taji, Kecamatan Pariaman Selatan, Kota Pariaman dengan luas $600 \mathrm{~m}^{2}$. Lahan perkebunan ini terganggu oleh kehadiran semut yang menyerang tanaman buah naga. Informasi mengenai intensitas serangan semut pada tanaman buah naga di Nagari Kurai Taji, Kecamatan Pariaman Selatan, Kota Pariaman belum pernah dilaporkan sebelumnya.

\section{Metode Penelitian}

Sampel tanaman dikoleksi dari kebun buah naga di di Nagari Kurai Taji, Kecamatan Pariaman Selatan, Kota Pariaman, Sumatera Barat. Metode yang digunakan dalam penelitian ini adalah metoda free collection dengan teknik porposive sampling. Pengamatan dilakukan pada $10 \%$ dari total jumlah tanaman yang terdapat pada perkebunan buah naga Semut yang diamati pada tanaman sampel, dikoleksi kemudian diidentifikasi di laboratorium untuk diketahui jenisnya. Pengidentifikasian sampel semut dilakukan di Laboratorium Taksonomi Hewan, Jurusan Biologi, Fakultas Matematika dan Ilmu Pengetahuan Alam, Universitas Andalas, Padang dengan merujuk pada buku (Jaitrong, Weeyawat and J. Nabhitabhata, 2005).

\section{Pengamatan intensitas serangan semut pada perkebunan buah naga}

Data persentase serangan semut pada perkebunan buah naga didapatkan dengan menghitung tanaman yang menunjukkan gejala bintik hitam akibat gigitan semut. Persentase tanaman terserang dihitung dengan menggunakan rumus Mohammed et al. (1999):

$$
\mathrm{P}=\frac{(\mathrm{n} \times \mathrm{v})}{\mathrm{Z} \times \mathrm{N}} \times 100 \%
$$

\section{Keterangan :}

$\mathrm{P}=$ intensitas kerusakan tanaman buah naga

$\mathrm{n}=$ Jumlah tanaman yang memiliki nilai $\mathrm{v}$ yang sama

$\mathrm{v}=$ nilai skala tiap kategori serangan

$\mathrm{Z}=$ nilai skala kategori serangan tertinggi

$\mathrm{N}=$ banyaknya tanaman buah naga yang diamati.

Penilaian tingkat kategori serangan menggunakan skoring 0 sampai 5 (Mohammed et al., 1999) yaitu :

$$
\begin{aligned}
& 0=\text { tidak ada kerusakan } \\
& 1=\text { tingkat kerusakan }>0-20 \% \\
& 2=\text { tingkat kerusakan }>20-40 \% \\
& 3=\text { tingkat kerusakan }>40-65 \% \\
& 4=\text { tingkat kerusakan }>65-80 \% \\
& 5=\text { tingkat kerusakan }>80-100 \%
\end{aligned}
$$

dengan kriteria serangan sebagai berikut: $0 \%=$ Tidak ada serangan; 1\%-20\%= serangan ringan; $20,1 \%-40 \%=$ serangan agak berat; $40,1 \%-60 \%=$ serangan berat, $>60 \%=$ serangan sangat berat.

\section{Hasil dan Pembahasan}

Pada penelitian mengenai intensitas serangan semut pada tanaman buah naga, ditemukan sebanyak 6 jenis semut yang mengunjungi tanaman buah naga, jenis tersebut adalah Tapinoma melanocephalum (Fabricus, 1793), Tetramorium pacificum (Mayr, 1870), Polyrachis (Cyrtomyrma) sp. of $\mathrm{HH}$, Solenopsis geminata (Fabricus, 1804) dan Monomorium florica (Jerdon, 1851), terdapat dua jenis semut yang tidak didapatkan oleh Herwina et al., (2014) pada perkebunan buah naga di Sumatera Barat yaitu dari genus Polyrachis dan Tetramorium. Hal tersebut disebabkan karena adanya perbedaan vegetasi pada masing-masing kebun buah naga. 
S. geminata ditemukan dengan jumlah individu paling banyak, diikuti oleh $T$. melanocephalum. T. melanocephalum ditemukan pada tanaman buah naga akan tetapi tidak menimbulkan kerusakan pada tanaman buah naga, sedangkan $S$. geminata merusak tanaman dengan cara menggigit serta menimbulkan lubang pada tanaman buah naga.

Intensitas serangan semut S. geminata pada tanaman buah naga Nagari Kurai Taji, Kecamatan Pariaman Selatan, Kota Pariaman, Sumatera Barat.

Persentase rata-rata intensitas serangan semut $S$. geminata pada perkebunan buah naga adalah 25\% (Tabel 1). Data ini menunjukan bahwa persentase serangan dapat dikatakan agak berat pada perkebunan buah naga. Menurut Agrios (1997), intensitas serangan semut dipengaruhi oleh faktor lingkungan di sekitar area pertanaman tersebut yang mendukung semut untuk menyerang, termasuk suhu dan kelembaban.

Lakshmikantha et al., (1996) melaporkan bahwa semut ini menimbulkan kerugian karena mengerogoti batang dari umbi kentang. $S$. geminta juga memakan biji gulma dalam beberapa kasus pertanian di Eropa (Way and Khoo, 1992). Penelitian yang dilakukan di Eropa oleh Bellec et al., (2006) melaporkan semut yang menjadi hama di pertanaman buah naga biasanya berasal dari genus Atta dan Solenopsis. Semut terkadang ditemukan pada buah dan bunga tanaman buah naga yang masih kuncup (Mizrahi and Nerd, 1999). Sebagai perbandingan Pheidole megacephala dan Linepithema humile hanya menyebabkan kerusakan ringan pada tanaman buah naga di Hawai (Chang and Ota, 1976).

$S$. geminata adalah semut predator yang banyak ditemukan baik di ekosistem yang telah dikelola manusia (Agroekosistem) maupun ekosistem asli (Wetterer dan Snelling, 2006). Selain berfungsi sebagai predator, semut dapat juga dijadikan indikator terjadinya kontaminasi pestisida pada ekosistem (Matlock dan Cruz, 2003).

Tabel 1. Persentase serangan semut pada buah naga di Nagari Kurai Taji, Kecamatan Pariaman Selatan, Pariaman, Sumatera Barat.

\begin{tabular}{ccc}
\hline $\begin{array}{c}\text { Buah } \\
\text { Naga }\end{array}$ & $\begin{array}{c}\text { Nilai skala } \\
\text { kategori } \\
\text { serangan (V) }\end{array}$ & $\begin{array}{c}\text { Intensitas } \\
\text { kerusakan } \\
\text { tanaman }(\%)\end{array}$ \\
\hline 1 & 2 & 20 \\
2 & 3 & 30 \\
3 & 2 & 20 \\
4 & 2 & 20 \\
5 & 3 & 30 \\
6 & 3 & 30 \\
7 & 2 & 20 \\
8 & 2 & 20 \\
9 & 3 & 30 \\
10 & 3 & 30 \\
11 & 3 & 30 \\
12 & 2 & 20 \\
\hline \multicolumn{3}{c}{ Rata-rata }
\end{tabular}

Kondisi tanah kemungkinan merupakan salah satu faktor penyebab tingginya jumlah $S$. geminata pada perkebunan buah naga. Tanah yang kering merupakan sarang yang baik untuk semut ini menyimpan makanan. Menurut Carroll and Risch (1983) S. geminata menyimpan makanannya didalam lubang yang dibuat di dalam tanah yang kering, semakin tinggi gundukan sarang berarti semakin banyak makanan yang disimpan.

Berdasarkan pengamatan di lapangan jika satu tunas muda dalam satu batang buah naga diserang oleh $S$. geminata maka tunas muda yang lainnya juga akan terserang. Hama semut ini biasanya muncul ketika tanaman buah naga mulai muncul kuntum bunga yang mengakibatkan kulit buah menjadi berbintik-bintik. Jika serangan semut ini parah maka akan mengakibatkan pentil buah naga menjadi kerdil bahkan mudah rontok dan semut ini biasanya juga muncul pada saat tumbuh tunas atau cabang baru. 


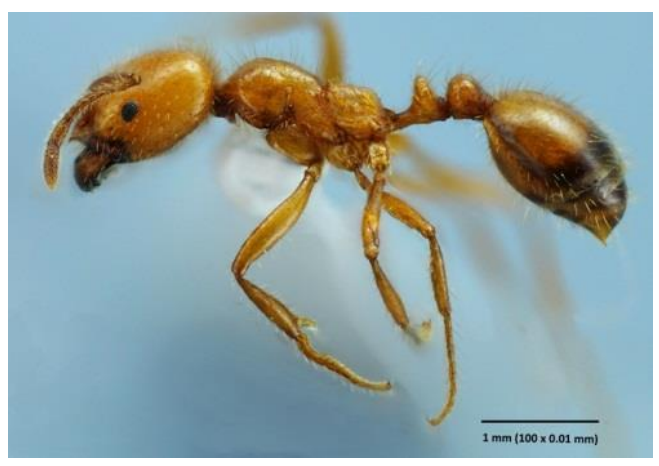

Gambar 1. Morfologi lateral tubuh semut Solenopsis geminata Fabricius, 1804) yang ditemukan pada perkebunan buah naga di Nagari Kurai Taji, Kecamatan Pariaman Selatan, Pariaman, Sumatera Barat.

Data Departement of Agriculture of US, 2011; FAO, 2015; PPD, 2006) melaporkan $S$. geminata sebagai salah satu jenis semut yang menjadi hama diperkebunan buah naga yang menyerang bagian buah, bunga dan juga bagian akar, hal ini juga sejalan dengan yang dilaporkan Cuc (2000) bahwa kerusakan yang disebabkan oleh semut akan meimbulkan bintik-bintik putih yang dikelilingi oleh warna hijau kegelapan, akan tetapi kondisi ini tidak sampai merusak kedalam daging buah. Dalam kasus lain, kerusakan yang ditimbulkan oleh gigitan semut akan menimbulkan bintik-bintik hitam pada buah yang hampir matang.

Serangan semut ini kemungkinan disebabkan oleh sistem budidaya tanaman secara monokultur, jarak tanam yang rapat yang menyebabkan semut dapat berpindah dengan mudah. Chou (2006), menyatakan bahwa monokultur yang merupakan cara budidaya perkebunan dengan menanam satu jenis spesies pada satu areal yang luas, dapat menimbulkan resiko penyakit yang besar karena dapat memudahkan penyebaran hama penyakit pada tanaman.

Jumjunidang (komunikasi pribadi) juga menemukan serangan semut $S$. geminata pada beberapa perkebunan buah naga di Sumatera Barat, bekas gigitan dari $S$. geminata dapat menjadi sumber infeksi bagi patogen penyakit untuk berkembang, sehingga apabila perkebunan buah naga diserang dalam intensitas yang tinggi oleh semut ini, dapat menyebabkan masalah yang serius bagi perkebunan buah naga.

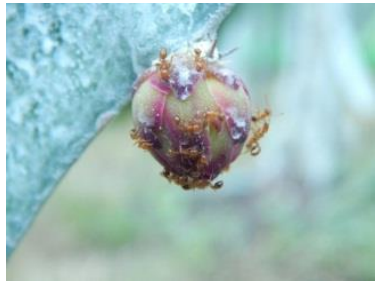

(A)

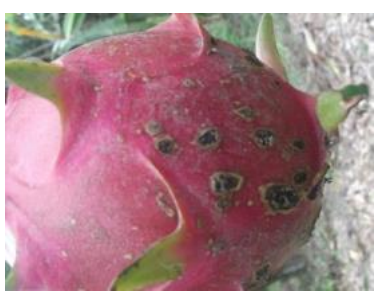

(C)

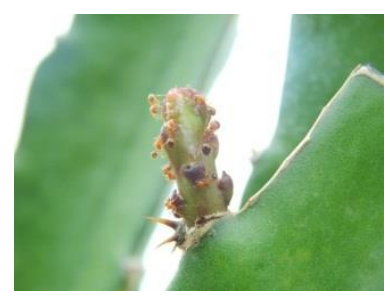

(E)

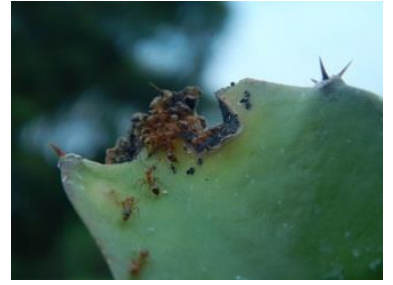

(B)

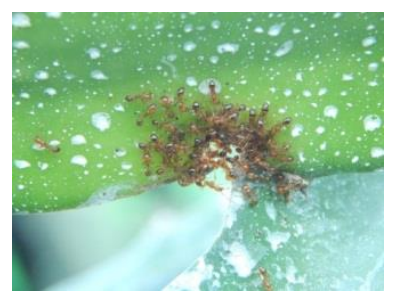

(D)

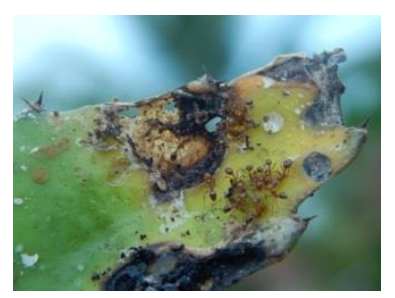

(F)
Gambar 2. Tanaman buah naga dan semut yang menyerang perkebunan buah naga di Nagari Kurai Taji, Kecamatan Pariaman Selatan, Pariaman, Sumatera Barat (A) Bakal calon buah yang digigit S. geminata; (B) penampilan batang buah naga setelah digigit $S$. geminata; (C) Bintik hitam pada buah yang digigit $S$. geminata; (D) $S$. geminata sedang menggigit batang buah naga; (E) Tunas baru yang sedang dikelilingi oleh S. geminata; (F) Bagian batang yang berlendir disebabkan oleh gigitan S. geminata. 


\section{Kesimpulan}

Intensitas serangan semut pada kebun buah naga di Kecamatan Pariaman Selatan, Padang Pariaman didapatkan dengan rata-rata $25 \%$ (termasuk dalam kategori agak berat) yang disebabkan oleh serangan semut Solenopsis geminata.

\section{Ucapan Terima Kasih}

Ucapan terima kasih disampaikan kepada Prof. Dahelmi, Dr. Resti Rahayu dan Izmiarti M.S atas semua masukan dan sarannya untuk penelitian ini, Rijal Satria M.Sc, Robby Janatan M.Si, Jumjunidang dari BALITBU, Solok, Sumatera Barat yang telah membantu selama proses penelitian, serta staf Kantor UPT BPP Kecamatan Pariaman Selatan, Kota Pariaman, Sumatera Barat.

\section{Daftar Pustaka}

Department of Agriculture United States. 2011. Pest list for the importation of Dragon Fruit (multiple genera and species) into the Continental United Stated from Thailand. http://www.acfs.go. Pdf. 6 Januari 2016.

Agrios G. N. 1997. Plant Pathology. Academic Press. New York.

Bellec, F. L., F. Vaillant and E. Imbert. 2006. Pitahaya (Hylocereus spp.) A New Fruit Crop a Market with a Future. http:/www.caribfruits. pdf. Diakses pada 6 Januari 2016.

Carroll, C. R. and S. J. Risch. 1983. Tropical annual cropping systems: ant ecology. Environmental Management 7: 51-57.

Chang, V. C. S. and A. K. Ota. 1976. Fire ant damage to polyethylene tubing used in drip irrigation systems. Journal of Economic Entomology 69: 447450.

Chou, C. K. S. 2006. Monoculture, Species Diversification and Disease Hazards in Forestry. N.Z. Journal of Forestry 2(2): 20-34.

Cuc, N.T.T. 2000. Cay Thang Long Hylocereus undatus Haw. Cactaceae. In: Insect Pests and Mites of Fruit Plants in the Mekong Delta of Viet Nam and their Management, pp. 292-296. Nha Xuat Ban Nong Nhgiep, Ho Chi Minh City.

[FAO] Food and Agriculture Organization. 2015. Fruit of Vietnam. FAO Corporate Document Repository. http://www.fao.org . 6 Januari 2016.

Herwina dan Yaherwandi. 2012. Study of Ants (Hymenoptera: Formicidae) in Solok District Cacao Plantation, West Sumatera. Proseeding Semirata BKS-PTN B. Medan. ISBN 978-602-9155-20-8

Herwina, H., N. Nasir, Jumjunidang, dan Yaherwandi. 2013. The composition of ant species on banana plants with Banana Bunchytop virus (BBTV) symptoms in West Sumatera, Indonesia. Jurnal Asian Myrmicology 5: 151-161

Herwina. H., R. Satria., D. Putri and Ranny. 2014. Ant Species (Hymenoptera: Formicidae) in Dragon Fruit Plantation (Hylocereus spp.) of West Sumatra, Indonesia. The Asian Conference on the Life Sciences and Sustainability Official Proceedings. Hiroshima, Japan.

Jaitrong, Weeyawat and J. Nabhitabhata. 2005. A List of Known Ant Species of 
Thailand (Formicidae: Hymenoptera). National Science Museum. Thailand.

Jumjunidang, Riska dan Muas. 2012. Outbreak Penyakit Busuk Batang pada Tanaman Buah Naga di Sumatra Barat. Balittro. Solok.

Lakshmikantha, B. P., N. Lakshminarayan, G.T. Musthakali and G. K. Veeresh. 1996. Fire-ant damage to potato in Bangalore. Journal of the Indian Potato Association 23: 75-76.

Mairawita. 2012. Pola Penyebaran Penyakit dan Karkterisasi serta Mekanisme Transmisi Serangga Vector dalam Penyebaran Penyakit Darah Bakteri (Ralstonia Solanacearum Phylotipe IV) pada Tanaman Pisang. Disertasi Pasca Sarjana Universitas Andalas. Padang.

Matlock, R. B. Jr. and R. D. Cruz 2002. An Inventory of Parasitic Hymenoptera in Banana Plantation Under Two Pesticide Regimes. Agric Ecosyst and Environ 93: 147-164.

McMahon, G. 2003. Pitaya (Dragon Fruit). Northern Territory Government. Department Of Primary Industry, Fisheries And Mines. http://www.Nt.Gov 6 Januari 2016.

Merten, S. 2003. A Review of Hylocereus Production in USA. http://www.jpacd.org.pdf 6 Januari 2016

Mizrahi, Y and A. Nerd. 1999. Climbing and Columnar Cacti: New Arid Land Fruit Crops. In: Janick J. (Ed.), Perspective on New Crops and New Uses. USA. ASHS Press. Pp. 358366.

Mohammed, A. A., C. Mak, K. W. Liew and Y. W. Ho. 1999. Early Evaluation
Banana Plants at Nursery Stage for Fusarium Wilt Tolarance. dalam Banana Fusarium with Manageman. Towards substainable cultivation. Proceedings of the International workshop of the banana Fusarium wilt disease, Malaysia 18-20 October 1999. p147-186.

PPD. 2006. Vietnam Ministry of Agriculture and Rural Development, Plant Protection Department. List of pests associated with Dragon Fruit in Vietnam, in Draft of PRA report on Importation of Dragon fruit from Vietnam into the United States. http://www.pra.us 6 Januari 2016.

Way, M. J. and K. C. Khoo. 1992. Role of ants in pest management. Annual Review of Entomology 37: 479-503.

Wetterer, J.K. and R.R. Snelling, 2006. The Red Imported Fire Ant, Solenopsis invicta, in The Virgin Islands (Hymenoptera: Formicidae). Florida Entomologist 89(4): 431434.

Zee, F., C. R. Yen and M. Nishina. 2004. Pitaya (dragon fruit, strawberry pear). Fruit and Nuts (9) 1-3. 